\title{
KONSEP PENDIDIK BERWAWASAN MULTIKULTURAL DALAM LEMBAGA PENDIDIKAN ${ }^{1}$
}

\author{
Miftahur Rohman \\ STIT Bustanul ‘Ulum Lampung Tengah \\ miftahur1rohman@gmail.com
}

\begin{abstract}
abstrak
Benih-benih intoleransi yang berujung kekerasan yang dewasa ini merebak ditengarai akibat memudarnya nilai-nilai humanisme dan multikulturalisme bangsa ini. Pendidikan sebagai instrumen peradaban berperan dalam mengatasi hal tersebut. Pendidikan multicultural dapat menjadi solusi mengatasi dekadensi moral pelajar bangsa ini. Guru, sebagai bagian dalam sistem pendidikan, dituntut untuk tidak hanya menguasai ilmu-ilmu pengetahuan, tetapi juga diharapkan memiliki sikap multikultural seagai bekalnya mengajar. Mengingat komposisi sekolahsekolah di negeri ini acap diisi oleh pelajar dari diversitas etnik, agama, ras, dan golongan.
\end{abstract}

\section{Kata Kunci \\ pendidik, berwawasan multicultural, pendidikan}

\section{PENDAHULUAN}

Persoalan lain yang kerap muncul dalam dunia pendidikan adalah bentuk kekerasan yang menimpa siswa seperti tawuran, dan perkelahian antarsiswa. Kekerasan tersebut beragam baik kekerasan verbal maupun nonverbal. Tak jarang kekerasan tersebut menimpa guru maupun siswa yang mengakibatkan korban jiwa. Tak pelak, pendidikan yang seharusnya menjadi wadah persemaian benih-benih perdamaian justru menjadi wahana tindakan tak beradab yang bertolak belakang dengan nilai-nilai kemanusiaan dan keadilan.

1 Paper dipresentasikan dalam acara "Seminar Nasional: Masa Depan Pendidikan Indonesia” di STIT Bustanul ‘Ulum Lampung Tengah, 10 Pebruari 2018. 
Kasus teranyar terjadi di salah satu sekolah negeri di kabupaten Sampang yang menyebabkan meninggalnya guru SMAN 1 Torjun Sampang. Peristiwa tersebut cukup memilukan dan melukai hati kita semua. Seorang siswa didik tega menganiaya gurunya sendiri hingga meninggal hanya karena tidak terima ditegur saat membuat gaduh dalam proses pembelajaran.

Jika dicermati peristiwa tersebut terjadi saat jam belajar berlangsung. Kegiatan pembelajaran yang seharusnya dijadikan wahana untuk menempa diri, meningkatkan kualitas, dan menghilangkan ketidaktahuan justru menjadi peristiwa mencekam yang akan selalu diingat oleh siapa pun yang menyaksikannya sebagai peristiwa kelam yang menimpa dunia pendidikan. Hal ini menunjukkan pelajar-pelajar kita belum memiliki attitude yang baik serta akhlak yang terpuji yang seharusnya dimiliki oleh mereka. Fenomena seperti ini ditengarai diakibatkan nilai-nilai humanisme, keadilan, toleran, serta multikultural masih jauh api dari panggang dalam dunia pendidikan kita.

Pendidikan yang berpijak pada nilai-nilai humanisme dan multikulturalisme pada dasarnya mengacu pada prinsip-prinsi dan nilai kemanusiaan yang di ejawantahkan dalam pendidikan. Guru sebagai pelaku pendidikan yang bersentuhan langsung hendaknya memiliki karakter tersebut sehingga pada akhirnya dapat ia tularkan kepada peserta didiknya. Makalah ini akan mendiskusikan konsep guru berwawasan multikultural. Nilai-nilai tersebut sebagai bekal yang dapat ia gunakan dalam proses pembelajaran. Mengingat bahwa intoleransi dan kekerasan dalam pendidikan kerap terjadi dan tidak jarang melibatkan siswa sebagai pembelajar. 


\section{PENDIDIKAN MULTIKULTURAL}

\section{Pijakan Epistemologis}

Menurut Dede Rosyada (2014), pendidikan multikultural adalah proses pendidikan yang memberikan peluang yang sama pada seluruh generasi bangsa tanpa diskriminasi karena perbedaan etnik, budaya, dan agama. Selanjutnya memberikan penghargaan terhadap keragaman, dan yang memberikan hak-hak yang sama bagi etnik minoritas, dalam upaya memperkuat persatuan dan kesatuan, identitas nasional dan citra bangsa dimata dunia internasional

Sementara itu Zakiyuddin Baidhawy (2007) menyebutkan pendidikan multikultural mempunyai makna yang lebih luas sehingga memasukkan isu-isu lain seperti relasi gender, hubungan antar agama, kelompok kepentingan, kebudayaan dan subkultur, serta bentuk-bentuk lain dari keragaman

Dalam konteks pendidikan Islam, pendidikan multikultural adalah sikap menerima kemajemukan ekspresi budaya manusia dalam memahami pesan pesan utama agama, terlepas dari rincian anutannya. Basis utamanya dieksplorasi dengan melandaskan pada ajaran Islam, sebab dimensi Islam menjadi dasar pembeda sekaligus titik tekan dari konstruksi pendidikan (Naim and Sauqi 2008). Nilai-nilai dan ajaran multikultural tersebut bersumber dari wahyu (al-Quran dan Hadis) (Aly 2011). Proses pendidikan yang dikembangkan haruslah proses pendidikan yang menonjolkan ide keberagaman kebudayaan atau masyarakat multikultural yang mendukung sikap saling menghargai terhadap perbedaan di tengah masyarakat.

Berdasarkan definisi di atas, pendidikan multikultur adalah pedidikan yang mengajarkan nilai-nilai kemanusiaan, toleransi, serta sikap inklusif dalam kehidupan berbangsa, bernegara maupun beragama. Dengan demikian, perbedaan-perbedaan khususnya dalam praktik 
keagamaan tidak disikapi dengan sikap eksklusif dan fanatik golongan. Dalam pendidikan multikultur, keragaman dan perbedaan menjadi nilai positif untuk mengembangkan potensi yang dimiliki masing-masing.

Dalam pendidikan multikultur, sekolah atau lembaga pendidikan harus merancang, merencanakan, dan mengontrol seluruh elemen sekolah yang dapat mendukung proses pendidikan multikultur dengan baik. Sekolah harus merencanakan proses pembelajaran yang dapat menumbuhkan sikap multikultur siswa yang menghargai perbedaan, menghargai hak asasi manusia dan keadilan. Sekolah harus mendisain pembelajaran, merancang kurikulum, sistem evaluasi, serta mempersiapkan pendidik yang memiliki perserpsi, sikap dan perilaku multikultur, sehingga menjadi bagian yang memberikan kontribusi positif terhadap pembinaan sikap multikultur para peserta didiknya (Rosyada 2014).

Guru menjadi bagian yang penting dalam mengembangkan pendidikan multikultural. Guru adalah profesi yang mulia. Karena gurulah yang membentuk karakter, kedisiplinan, kecintaan dan kasih sayang (McNergney and Carrier 1981). Perubahan perilaku peserta didik dipengaruhi oleh latar belakang pendidikan dan pengalaman yang dimiliki seorang guru. Dengan kata lain, baik dan buruknya seorang siswa tidak bisa terlepas dari kualitas guru tersebut (Hamzah 2007). Selain bekal keilmuan yang cukup, metodologi yang digunakan guru dalam mengajar harus diperhatikan. Teori-teori yang dirasa tidak relevan lagi digunakan harus dikritisi. Dengan kata lain, selain menjadi pengajar, guru juga menjadi researcher (Kincheloe 2001). 


\section{KONSEP GURU BERWAWASAN MULTIKULTURAL}

\section{Landasan Yuridis}

Menurut PP Nomor 74 Tahun 2008, Guru adalah pendidik profesional dengan tugas mendidik, mengajar, membimbing, mengarahkan, melatih, menilai, dan mengevaluasi peserta didik pada pendidikan anak usia dini jalur pendidikan formal, pendidikan dasar, dan pendidikan menengah. Sedangkan untuk pendidikan tinggi, pendidik yang bertugas memberikan pengajaran disebut dosen. Menurut UU Nomor 14 Tahun 2005 disebutkan, Dosen adalah pendidik profesional dan ilmuan dengan tugas utama mentransformasikan, mengembangkan, dan menyebarluaskan ilmu pengetahuan, teknologi, dan seni melalui pendidikan, penelitian, dan pengabdian kepada masyarakat. Guru adalah profesi yang mulia, karena guru merupakan sosok pertama yang mengenalkan kita pada ilmu-ilmu pengetahuan.

Berdasarkan definisi di atas, guru atau dosen tidak dapat dilepaskan dari pendidikan formal. Hanya saja tugas dan fungsinya yang sedikit berbeda. Guru sebagai pendidik pada lembaga pendidikan dasar dan menengah bertugas mentransformasikan ilmu pengetahuan kepada peserta didik (Transfer of Knowledge). Sedangkan dosen mempunyai tugas yang lebih tinggi dari guru. Selain sebagai tenaga pendidik pada jenjang pendidikan tinggi, dosen mempunyai tugas sebagai peneliti atau pembuat teori. Lebih-lebih guru besar yang harus mengembangkan research and development untuk mengembangkan ilmu pengetahuan dan teknologi.

\section{Guru Multikultural: Desain dan Implementasi}

Terlepas dari problem yang acap dihadapi seorang guru (Rohman 2016), guru hendaknya minimal memiliki empat peran dalam lembaga pendidik multikultur, yakni sebagai edukator, fasilitator, akomodator, dan assimilator (Rohman and Lessy 2017). Sebagai edukator dan fasilitator 
tentu sudah jamak diketuahui. Namun peran sebagai akomodator dan assimilator belum semua guru memahaminya. Peran tersebut akan menuntun guru menjadi sosok yang bijak dan akan mengakomodir semua pendapat anak didiknya. Selain itu, ia akan memahami apa yang dibutuhkan oleh peserta didiknya. Kemudian, guru dapat menjadi asimilator dikarenakan dalam suatu kelas bisa saja terdiri dari peserta didik yang berasal dari etnik dan budaya yang beragam. Untuk itu, guru berperan menyatukan perbedaan yang berpotensi menimbulkan perpecahan. Dengan demikian, asimilasi budaya dapat terjadi dalam lingkungan kelas. Sedangkan fungsi guru sebagai akamodator adalah memfasilitasi semua peserta didik yang berbeda-beda. Karena peserta didik memiliki kemampuan dan keinginan yang beragam. Bahkan, guru harus dapat memenuhi kebutuhan peserta didik yang berkebutuhan khusus.

Selanjutnya, desain pembelajaran harus mendukung tersiptanya iklim pendidikan yang harmonis, kondusif, serta edukatif. Karena pendidikan multikultural bukan hanya membina knowledge skill siswa, tetapi mendidik siswa untuk menjadi warga negara yang inklusif, pluralis, demokratis, menghargai HAM, dan keadilan. Untuk itu, diperlukan guru dan staf sekolah yang memiliki latar belakang yang beragam. Desain pendidikan berbasis nilai-nilai sosial-multikultural tersebut akan mengintegrasikan tiga tujuan pembelajaran siswa, yakni kecerdasan akademik, spiritual, dan sosial. 


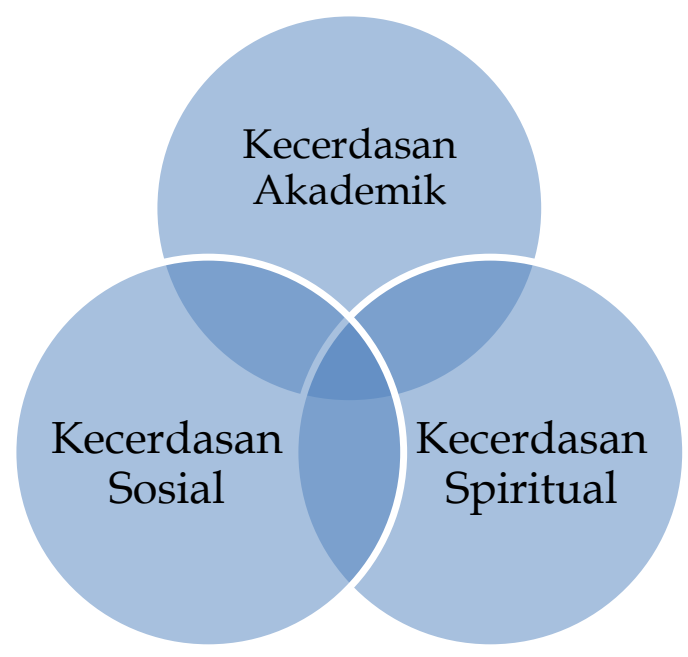

Gambar 1: tiga tujuan pembelajaran

Menurut Solomon, lembaga pendidikan multietnik dapat menggunakan teori 'integration model'. Teori ini mengusulkan ada perimbangan komposisi staf di sekolah (guru, staf administrasi, staf konseling dan lain-lain) yang berlatar belakang etnis dan ras yang berbeda (Cordeau, Pasin, and Solomon 2006). Terkait multikulturalisme, penelitian yang dilakukan Iwan Supardi di empat sekolah swasta di Kota Pontianak menunjukkan terjadi hubungan yang beragama antar etnis-agama. Pola interaksi tersbut mulai dari positif sampai negatif (Supardi and Sumarno 2014). Dalam penelitiannya di SMA Sultan Syarif Abdurrahman (MelayuIslam), SMA Yayasan Pendidikan Kristen (Dayak-Nasrani), SMA Kristen Immanuel (Tionghoa-Nasrani, Konghucu, Buda) dan MA Al-Anwar (Madura-Islam). Ia menyimpulkan terjadi hubungan yang bervariasi antar kelompok etnik-agama. Hubungan tersebut meliputi etno-sentrisme, cinta-benci, saling membenci atau berseteru, dan saling menyukai dan mendukung. Menurutnya, sejarah sosial kehidupan yang pincang pada masa lalu menampilkan profil dan karakter sekolah eksklusif, mengelompok, berorientasi pada etnis dan agama atau yang disebut secara teknis sebagai sekolah segresi etno-religi (ethno-religio segregation). 


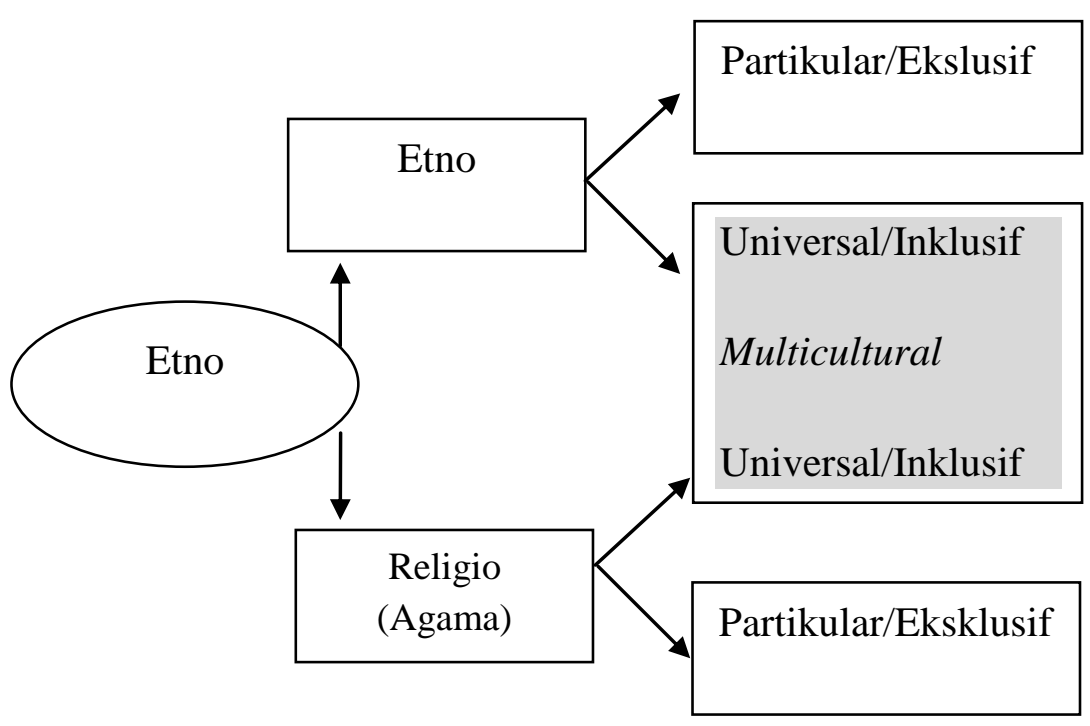

Gambar 2: Wilayah Potensial Pengembangan Pendidikan Multikultural Menurut Iwan Supardi

Dengan demikian, sekolah harus mengembangkan nilai-nilai perdamaian, toleransi, hak asasi manusia, demokrasi dan keadilan. Pendidik di sekolah berbasis etnik-agama tertentu sudah seharusnya mengajarkan nilai-nilai kemanusiaan dan keadilan universal yang menjunjung nilai-nilai keadilan dan perdamaian. Misalnya, sekolahsekolah dengan basis agama tertentu harus mengajarkan kepada peserta didiknya tentang nilai-nilai keagamaan secara universal. Pendidik harus menanamkan nilai perdamaian dan keadilan. Mereka harus mengajarkan tidak ada agama dan etnis tertentu yang mengajarkan kekerasan, diskriminasi dan terorisme.

Gollnick \& Chinn (1986) menyebutkan enam asumsi dasar mengapa pendidikan multikultural perlu dikembangkan di sekolah, yaitu:

1. Perbedaan budaya memiliki kekuatan nilai

2. Sekolah harus menjadi model penegakkan HAM dan keadilan

3. Keadilan dan kesetaraan semua warga sekolah harus menjadi perhatian yang penting dalam mengembangkan kurikulum 
4. Nilai-nilai demokratis dalam kehidupan masyarakat perlu dipromosikan di sekolah

5. Lembaga sekolah sebagai tempat untuk mengembangkan kognitif, afektif dan psikomotor siswa dari berbagai kelompok yang beragam

6. Kerjasama guru dengan pihak keluarga dan masyarakat dapat menciptakan lingkungan yang mendukung multikulturalisme.

Dari enam asumsi dasar diatas pada poin keenam, menekankan kerjasama guru dan pihak keluarga dan sekolah. Dengan demikian, guru menjadi pihak yang terlibat langsung dalam implementasi pendidikan yang multikultur. Metode dan pendekatan guru dalam mengajar harus mendukung dalam menegakkan pendidikan multikultural. Oleh sebab itu, guru hendaknya menggunakan metode dan pendekatan pembelajaran yang bervariasi.

Sementara itu, Jerry Aldridge dan Renitta Goldman (2007) merekomendasikan bahwa untuk meningkatkan kualitas proses pembelajaran agar dapat meningkatkan hasil belajar, seorang guru harus mengembangkan berbagai perlakuan sebagai berikut:

1. Guru harus mampu menciptakan situasi kelas yang tenang, bersih, tidak stress dan sangat mendukung untuk proses pembelajaran

2. Guru harus menyediakan peluang bagi para siswa untuk mengakses seluruh bahan dan sumber informasi untuk belajar.

3. Gunakan model pembelajaran cooperative learning yang tidak hanya model belajar bersama, namun saling membantu satu sama lain melalui diskusi dalam kelompok-kelompok kecil, debat atau bermain peran. Biarkan siswa untuk diskusi dengan suara keras dalam kelompoknya masing-masing, dan biarkan 
siswa saling membantu satu sama lain, serta saling bertukar informasi yang mereka dapatkan dari hasil aksesnya.

4. Hubungan informasi baru pada sesuatu yang sudah diketahui oleh siswa.

5. Dorong siswa untuk mengerjakan tugas-tugas penulisan makalahnya dengan melakukan kajian dan penelusuran pada hal-hal baru dan dalam kajian yang mendalam.

6. Guru juga harus memiliki catatan-catatan kemajuan dari semua proses pembelajaran siswa, termasuk tugas-tugas individual dan kelompok mereka dalam bentuk portofolio.

Enam poin di atas adalah langkah-langkah yang harus dilakukan guru beserta manajemen sekolah dalam rangka mencapai tujuan pembelajaran. Tujuan pembelajaran mencakup penguasaan materi mastery learning, yakni penguasaan materi minimal 80\%. Untuk itu, guru harus bersinergi dengan manajemen sekolah dan seluruh staf sekolah.

Kemudian dalam proses pembelajaran di kelas, guru sekali-kali dapat menyuruh peserta didik untuk membuat narasi tentang dirinya tentang kehidupan dan latar belakangnya darimana ia berasal. Narasi tersebut dipresentasikan didepan kelas. Sehingga teman-temannya yang lain tahu latar belakang kehidupan masing-masing setiap peserta didik. Langkah tersebut sebagai upaya untuk menjembatani gesekan yang sering terjadi antar suku di Indonesia. Misalnya, peserta didik yang berasal dari suku Jawa dapat mengisahkan latar belakang hidupanya, orang tuanya dan darimana ia berasal. Sehingga peserta didik lain dapat mengetahui dan memahaminya. Begitupun sebaliknya peserta didik yang berasal dari suku atau etnis yang lain. Kegiatan ini cocok diterapkan pada kelas yang terdiri dari peserta didik yang berasal dari etnis yang beragam.

Selain itu, dalam menyampaikan materi pelajaran guru juga dapat menggunakan teori Imre Lakatos tentang kebenaran. Menurut Imre 
Lakatos (1980), kebenaran ada yang disebut kebenaran mutlak (hard core) dan kebenaran relatif (lingkaran pendukung). Kebenaran mutlak atau hard core adalah kebenaran yang mutlak benarnya atau absolut. Sedangkan kebenaran relatif dapat berubah nilainya baik secara temporal atau dari sudut pandang mana kita memandang. Terori ini tepat digunakan dalam menyampaikan materi pendidikan agama Islam terutama pada materi figh, kalam dan al-Quran hadis.

\section{KESIMPULAN}

Pendidikan multikultural di Indonesia menjadi harapan untuk menjaga persatuan dan kesatuan bangsa di tengah perbedaan dan konflik yang kerap terjadi. Sebagaimana hasil penelitian yang peneliti lakukan sebelaumnya, pendidikan hendaknya berbasis pada nilai-nilai sosialmultikultural untuk mendukung tercapainya tujuan pedidikan (Rohman and Mukhibat 2017). Institusi pendidikan seperti sekolah harus mengimplementasikan metode pendidikan ini dalam kegiatan belajar mengajarnya. Berdasarkan isi tulisan ini, dapat diambil kesimpulan sebagai berikut:

1. Sebagai institusi pendidikan, sekolah harus mengembangkan pendidikan multikultural sedini mungkin. Pengembangan tersebut harus mencakup seluruh aspek mulai dari kurikulum, sarana dan prasarana, peserta didik dan pendidik.

2. Pendidik harus bekerjasama dengan manajemen sekolah untuk mengembangkan pendidikan multikultural.

3. Pendidik dan peserta didik dalam sebuah sekolah harus terdiri dari berbagai macam latar belakang etnis yang dapat mewakili keberagaman etnis di Indonesia. 
4. Disain, strategi dan pendekatan pembelajaran yang dibuat guru harus bervaruiasi, mulai dari cooperativ learning, active learning, student center maupun teacher center.

5. Guru harus menjadi asimilator dan akamodator.

6. Dalam menyampaikan materi, guru harus mampu membedakan antara kebenaran mutlak/absolut dan kebenaran relatif. Untuk hal ini dapat menggunakan teori Imre Lakatos.

Selanjutnya untuk menjadi guru yang multikultural penulis tawarkan langkah-langkah sebagai berikut:

1. Guru harus membuka pelajaran dengan doa sesuai kepercayaan masing-masing siswa sebelum dimulai pembelajaran.

2. Guru harus memilih ketua kelas dan wakil ketua kelas yang terdiri dari siswa putra dan putri untuk mewakili jender masing-masing.

3. Guru dapat menukar bangku duduk siswa secara bergantian setiap hari agar terjadi keadilan untuk seluruh siswa.

4. Guru memberikan kesempatan yang sama kepada seluruh siswa laki-laki maupun perempuan untuk bertanya dan mengemukakan pendapatnya.

5. Guru dapat mengintegrasikan materi pembelajaran dengan kearifan lokal budaya dan adat yang ada di Indonesia. 


\section{REFERENCES}

Aldridge, Jerry, and Renitta L Goldman. 2007. Current Issues and Trends in Education. Allyn \& Bacon.

Aly, Abdullah. 2011. "Pendidikan Islam Multikultural Di Pesantren." Yogyakarta: Pustaka Pelajar.

Baidhawy, Zakiyuddin. 2007. "Building Harmony and Peace through Multiculturalist Theology- based Religious Education: An Alternative for Contemporary Indonesia." British Journal of Religious Education 29(1): 15-30.

Cordeau, Jean-François, Federico Pasin, and Marius M Solomon. 2006. "An Integrated Model for Logistics Network Design." Annals of operations research 144(1): 59-82.

Gollnick, Donna M, and Philip C Chinn. 1986. Multicultural Education in a Pluralistic Society. ERIC.

Hamzah, B Uno. 2007. “Profesi Kependidikan.” Jakarta: Bumi Aksara.

Kincheloe, Joe L. 2001. Getting beyond the Facts: Teaching Social Studies/social Sciences in the Twenty-First Century. P. Lang.

Lakatos, Imre. 1980. 1 The Methodology of Scientific Research Programmes: Volume 1: Philosophical Papers. Cambridge university press.

McNergney, Robert F, and Carol A Carrier. 1981. Teacher Development. Macmillan College.

Naim, Ngainun, and Achmad Sauqi. 2008. Pendidikan Multikultural: Konsep Dan Aplikasi. Ar-Ruzz Media.

Rohman, Miftahur. 2016. “Problematika Guru Dan Dosen Dalam Sistem Pendidikan Di Indonesia." Cendekia: Journal of Education and Society 14(1): 49 .

Rohman, Miftahur, and Zulkipli Lessy. 2017. "Practicing Multicultural Education through Religiously Affiliated Schools and Its Implications for Social Change." Jurnal Pendidikan Islam 6(1): 1-24.

Rohman, Miftahur, and Mukhibat Mukhibat. 2017. "Internalisasi NilaiNilai Sosio-Kultural Berbasis Etno-Religi di MAN Yogyakarta III." 
Edukasia: Jurnal Penelitian Pendidikan Islam 12(1): 31.

Rosyada, Dede. 2014. "Pendidikan Multikultural Di Indonesia Sebuah Pandangan Konsepsional." SOSIO-DIDAKTIKA: Social Science Education Journal 1(1): 1-12.

Supardi, Iwan, and Sumarno Sumarno. 2014. "MODEL PENDIDIKAN MULTIKULTURAL RAMAH DI SEKOLAH ETHNO-RELIGIO SEGREGATION (E-RS) KOTA PONTIANAK." Jurnal Penelitian dan Evaluasi Pendidikan 18(2): 202-14. 